\title{
THEORETICAL VIEWS ON THE CONCEPT OF “PROPERTY” IN SECULAR LINGUISTICS
}

\author{
Shokirova Diloramkhon Abduvali Qizi
}

Teacher, Interfaculty Of Foreign Languages (Social Sciences And Humanities), Andijan State University, Uzbekistan

\section{ABSTRACT}

This article discusses the most common methods of studying the concept in modern linguistics, conceptual analysis is the main method of conceptual description of the multifaceted "property" phenomenon, allows to observe the ways of knowing the meaning of the concept of "property" and record the result in the official semantic language.

KEYWORDS: - Concept, conceptual description, slot, hierarchy, comparative-contrast method of description.

\section{INTRODUCTION}

Despite many theoretical studies and individual studies of individual concepts that have been actively developed in recent years, linguistics still lacks a single accurate, clear, and unambiguous definition and universally accepted methodology of concept study. This is also due to the fact that "not all fields of the concept are at the same level of hierarchy" because some of them were formed earlier and others later. Consequently, some of the fields are more precise and others are more abstract and are formed on the basis of existing fields. It follows that, depending on the abstraction of the field being formed, the focus of the purpose of perception can be focused only on the perceived object or only on the already existing areas of the relevant concept". The blurring of the boundaries of concepts and the lack of uniformity in the methods of their study are also related to the universally recognized relativity of linguistic knowledge, their subjectivity, the magnitude of the role of the human factor in language. Even as D.S. Likhachev points out, "a concept is the result of a collision of lexical meaning with human experience, and the broader and richer the concept, the broader the experience".

Let us consider the most common methods of concept study in modern linguistics.

\section{Methods}

The main research method in the study of concepts is the application of the method of conceptual analysis, the purpose of which is to know the mental structure of the word 
CURRENT RESEARCH JOURNAL OF PEDAGOGICS 2(12): 185-188,

December 2021 DOI: https://doi.org/10.37547/pedagogics-crjp-02-12-36

ISSN 2767-3278

(C)2021 Master Journals

Crossref dof 81 Google

Accepted 26 $6^{\text {th }}$ December, 2021 \& Published 31 ${ }^{\text {th }}$ December, 2021

associated with a particular part of linguistic reality.

A study of the works of various authors who clearly state that they are engaged in conceptual analysis shows that conceptual analysis is in no way a particular way (method, technique) of explaining concepts. The work is combined with some relatively common goal, and as for the ways to achieve it, it would be more accurate to say that they turn out to be completely different. It should be noted that profound differences exist not only in research methods (i.e., in what is considered analysis), but also in what is primarily considered to be the result in certain studies.

In our research work, conceptual analysis is the main method of conceptual description of the multifaceted phenomenon of "property", which allows us to follow the path of knowing the meaning of the concept of "property" and record the result in formalized semantic language. We also use the method of S.G.Vorkachev and I.A.Tarasova for determining the main dominants of the concept.

In this study, the role of the mental linguistic model of the concept of "property" is played by a certain structure of knowledge, combined with the state cogniotype, i.e. the concept of "property". The aims of the research work is to objectify the content of the concept of "property" in the minds of Uzbek and English linguists and to determine the semantic structure of this concept and its elements. Based on the description of "property" in religious books and its reflection in the hadiths, as well as the analysis of lexical information, a list of linguistic units associated with "property" is formed, which forms the basis of the cognitive structure of the concept and synonyms and words in English and Uzbek.

At the final stage of the research work, the method of comparative-contrastive description is used, which allows to identify common features and the most important differences in the expression of the concept of "property" in English and Uzbek. It concludes with the analysis of the concept of "property" step-by-step according to the methodology of I.A.Tarasova, which distinguishes the levels of "conceptual, subject, associative, figurative, symbolic and evaluative". Although this method was created and used to analyze artistic concepts, it allows us to identify the leading means of communicating a particular concept. We believe that this can be applied to the concept of "property", as it can be expressed both as a cultural concept and as an artistic concept when incorporated into an artistic text, that there are many examples.

Because we rely mainly on dictionary material, and a typical example of declarative knowledge can be considered as the interpretation of words in simple explanatory dictionaries. Because the use of a frame as a cognitive structure is a very logical and natural epistemological choice.

Typically, the frame is presented in tabular form for clarity, whose rows represent the slots; each slot has its own name and content. We do the same in order to present the concept of "property" in the form of frames in Uzbek and English.

Frames usually have a structure in the form of meanings and relationships. The higher levels of the frame contain meanings that are clear and specific to the situation. The lower level slots will be filled with information depending on the situation.

The bottom and top can be understood as the contents of the slots.

The frame "Property" is in Uzbek 
CURRENT RESEARCH JOURNAL OF PEDAGOGICS 2(12): 185-188,

December 2021 DOI: https://doi.org/10.37547/pedagogics-crjp-02-12-36

ISSN 2767-3278

(C)2021 Master Journals

Crossref do: 81 Google

Accepted 26 $6^{\text {th }}$ December, 2021 \& Published 31 ${ }^{\text {th }}$ December, 2021

\begin{tabular}{|l|l|}
\hline \multicolumn{1}{|c|}{ Names of slots } & The composition of slots \\
\hline $\begin{array}{l}\text { 1. Theme: property } \\
\text { 2. Object: property }\end{array}$ & $\begin{array}{l}\text { 1. A. availability 1.B. absence } \\
\text { 2.A. treasure, material values } \\
\text { 2.B. money 2.C. any precious things } \\
\text { 3. Attitude to norm }\end{array}$ \\
4. Evaluation & $\begin{array}{l}\text { 3.A. norm 3.B. more } \\
\text { aesthetic }\end{array}$ \\
5. Cost & 5. high \\
6. Classification of the language & 6.A. features 6.B. abstract features 6.C. \\
& dynamic features. 6.D. features of the \\
& mark
\end{tabular}

A.N. Baranov and D.O. Dobrovolsky suggest the use of frames to describe the mechanisms of revaluation of meanings. In their view, "figurative meaning is not the result of a change in the relevant direct meaning, but the result of developments on relevant cognitive structures".

The given frame is interpreted as a generator of basic meanings, the question may arise as to what distinguishes it from the meaning of the word, or relies on the meaning of the component content in the form of similar semantic terms. As A.N. Baranov rightly points out, "in terms of content, the concept of a frame is very close to the category of interpretation. Indeed, the valence analogue of the slots is the analogue of the slot filling actant. The main difference between them that the interpretation contains only linguistically relevant information about the meaning of the word. Including all relevant information for the problem situation".

For example, in the above example (the second meaning) the frame of "nature" includes one of its slots, for example, "resources" and accordingly activates extralinguistic information related to it: oil, gas, minerals, forests, water and so on.

There may be a question about the legitimacy of the inclusion of linguistic features of the frame. Interestingly, Ch. Fillmore puts it this way: "We can use a term frame that has a specific lexical and grammatical meaning for nouns and relationships found in the given language diagrams".

In the research work of the socio-cultural concept of "property", the main artistic and literary texts, religious books are to create a holistic image of the object under consideration. The influence of religious books in the history, mentality and language of nations is enormous for thousands of years.

\section{REFERENCES}


CURRENT RESEARCH JOURNAL OF PEDAGOGICS 2(12): 185-188,

December 2021 DOI: https://doi.org/10.37547/pedagogics-crjp-02-12-36

ISSN 2767-3278

(C)2021 Master Journals

Crossref do: 81 Google

Accepted 26 ${ }^{\text {th }}$ December, $2021 \&$ Published 31 ${ }^{\text {th }}$ December, 2021

1. D. Kazakbayeva. The words with the semantics of "ear" pragmatic properties in the Uzbek languages. InterConf. 2021/8/22. 223-229p.

2. Sh.Shokirov. "Lexical-semantic field of the "eye" in different structural languages and the typology of its constituent language units". PhD. in Philosophy and Philology. Abstract - T.2020

3. Shamatova O. Sh., Kazakbayeva D. I. Pedgogical problems of creating English textbooks. Journal NX, VOLUME 7, №1, 109-112p.

4. Мюллер В. К. Англо-русский словарь / под ред. - 24-е изд. - М.: Русский язык, 1995. - 2106 c.

5. Ожегов С. И. Словарь русского языка. М.: ГИИНС, 1961. - С. 900.

6. Рахматуллаев Ш. Ўзбек тилининг изохли фразеологик луғати. - Т.: Университет, 1978. - Б. 73-197.

7. Хошимов Г.М. К теории концептов и их таксономики в когнитивной лингвистике. // Систем-структур тилшунослик муаммолари. Филология фанлари доктори, профессор Н.К.Турниёзов таваллудининг 70йиллигига бағишланган Республика илмий-назарий конференцияси материаллари. Самарканд, 2010

8. Шенк Р., Абельсон, планы и знание // Труды ИВ межд. конф. по искусств, интеллекту, т. 6. М.: Научн. совет по компл. пробл. "Кибернетика" АН СССР, 1975.- С. 208 - 220.

9. Яхина А. М. Оценочность как компонент значения фразеологических единиц в русском, английском и татарском языках (на материале ФЕ, обозначающих поведение человека).
Дисс. ... канд. филол. наук. - Казань, 2008.

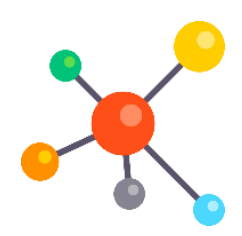

